\title{
CALCIUM METABOLISM IN A CASE OF GARGOYLISM, STUDIED WITH THE AID OF RADIOCALCIUM ${ }^{1}$
}

\author{
By FELIX BRONNER,² CLEMENS E. BENDA, ROBERT S. HARRIS, AND \\ JOSEPH KREPLICK ${ }^{3}$ \\ (From the Department of Food Technology, Massachusetts Institute of Technology, Cambridge, \\ the Department of Neuropsychiatry, Harvard Medical School, Boston, and the Walter \\ E. Fernald State School, Waverly, Mass.)
}

(Submitted for publication July 16, 1957; accepted October 7, 1957)

A number of studies have been reported on the fate of radiocalcium $(\mathrm{Ca}-45)$ in humans (1-12), but none have included chemical analyses of the concentration of $\mathrm{Ca}-45$ in the skeleton and in such tissues as liver, brain, or intestinal tract. We are now reporting the results of a metabolic study with Ca-45 performed on a 10 year old patient with terminal gargoylism. The analyses of periodic samples of serum, urine, cerebrospinal fluid, and feces obtained during the patient's illness and of various tissues removed at necropsy 16 days after the administration of $\mathrm{Ca}-45$ have made it possible to formulate a relatively complete picture of the calcium metabolism of this individual, although the lack of comparable information makes it difficult to evaluate whether and how gargoylism modified the calcium metabolism of our patient.

Gargoylism is now well recognized clinically (13), but its pathogenesis is largely unknown. Evidence is accumulating (14-19) to indicate that gargoylism is a storage disease, characterized by the accumulation of abnormal types (20) and quantities of mucopolysaccharides in a large variety of tissues, notably liver and spleen.

Recently, it was proposed that polysaccharides, such as chondroitin sulfate, are involved in the calcification process in bone and cartilage [see Amprino (21) for a review of the evidence]. Although gargoylism appears to be characterized by a defect in structural polysaccharides, it is possible

\footnotetext{
1 Support for this study came in part from the United States Public Health Service, and in part from the National Foundation for Infantile Paralysis. Contribution No. 342 from the Department of Food Technology, Massachusetts Institute of Technology, Cambridge, Mass.

2 Present address: Hospital for Special Surgery, New York Hospital-Cornell Medical Center, 535 East 70th Street, New York, N. Y.

3 Present address: Massachusetts Memorial Hospital, Boston, Mass.
}

that calcification is also defective in this condition. Dawson (17) has reviewed the histological changes seen in the bones of patients with gargoylism and has concluded that the changes are dystrophic and are probably of direct metabolic origin. However, no metabolic studies have been reported. It seemed of interest, therefore, to study in detail the calcium metabolism of a patient with terminal gargoylism.

\section{MATERIAL AND METHODS}

Description of patient. The patient was a male child, 9 years 10 months old, $137 \mathrm{~cm}$. high, who weighed 16.4 $\mathrm{Kg}$. He had been institutionalized since the diagnosis of the disease almost five years earlier. When the study was initiated, the disease had progressed to a point where the boy's life expectancy appeared short. The patient was almost completely unaware of his surroundings, had lost his ability to communicate except by a bird-like whine, and showed no response to sounds. He appeared incapable of any muscular control, was incontinent of urine and feces, and had to be handled like a 3 months old baby. His arms and legs were flexed, with ankylosis of the joints. The hands were clenched, the fingers showed clubbing, and the skin was taut and shiny. There was general hirsutism.

Design. Although the patient was on the danger list, his condition had remained unchanged for several weeks preceding the study. It was planned to follow the course of the injected $\mathrm{Ca}-45$ intensively during the first five days, then at weekly, and later at monthly intervals. The death of the patient on Day 16 prevented an extended follow-up.

Dietary regimen. Before the initiation of the study and throughout its duration, the patient was spoon-fed with commercial baby foods, baby cereals, and milk. No attempt was made to regulate his intake. During the course of the study, i.e., on days when specimen collection was carried out, food equivalent to that fed to the patient was collected by having the nursing personnel place in a collection jar quantities of food identical to those fed the patient. His calcium intake was analyzed as 3.8 Gm. on Day 1, 5.2 Gm. on Day 2, $4.3 \mathrm{Gm}$. on Day 3, 


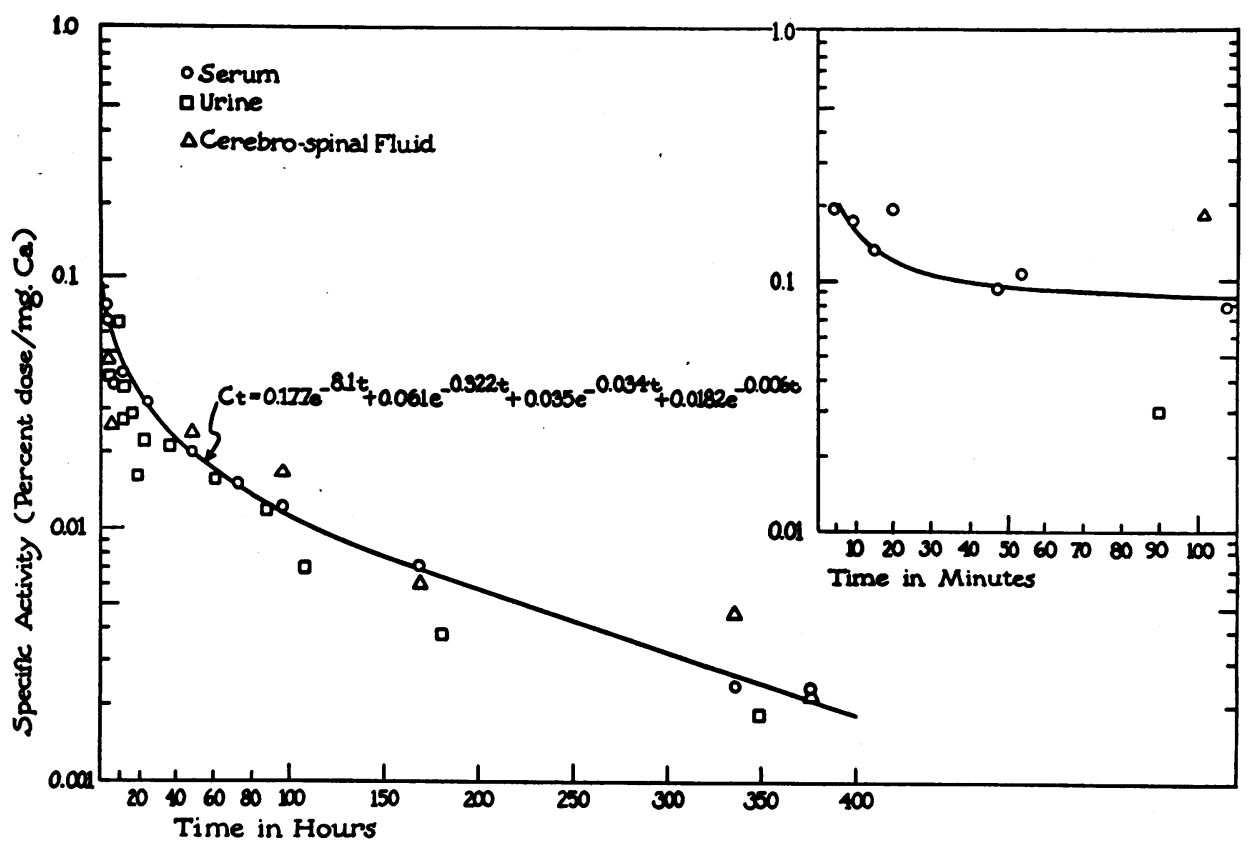

Fig. 1. Specific Activity of Serum, Urine and Cerebrospinal Fluid of a Patient with Gargoylism Following Intravenous InJeCtion of $80 \mu \mathrm{C}$. of $\mathrm{CA}_{\mathrm{A}}-45 \mathrm{CI}_{2}$

The equation predicts the course of the specific activity of the serum with time. $C_{t}$ equals per cent dose per mg. Ca, $t$ equals hours. Average calcium content of serum: $0.085 \mathrm{mg}$. per $\mathrm{ml}$; range, 0.081 to 0.090 . Average calcium content of cerebrospinal fluid: $0.049 \mathrm{mg}$. per ml.; range, 0.044 to 0.059 .

$1.3 \mathrm{Gm}$. on Day 4, $1.0 \mathrm{Gm}$. on Day 5, $0.5 \mathrm{Gm}$. on Day 8, and $3.2 \mathrm{Gm}$. on Day 15.4

Calcium-45.5 The Ca-45 was diluted in a solution containing 0.8 per cent of $\mathrm{NaCl}$ and 0.1 per cent of $\mathrm{CaCl}_{2}$. A total of $3 \mathrm{ml}$. of solution was injected intravenously; it contained $80 \mu \mathrm{c}$. of $\mathrm{Ca}-45,1 \mathrm{mg}$. of $\mathrm{Ca}^{++}, 10 \mathrm{mg}$. of $\mathrm{Na}^{+}$, and $16 \mathrm{mg}$. of chloride, and had been sterilized by autoclaving.

Specimen collections. Blood was obtained by venipuncture at intervals indicated in Figure 1. Samples of cerebrospinal fluid were obtained by spinal puncture (Figure 1). Urine samples were obtained from the catheterized patient at three hour intervals during the first day; thereafter (Days 2 to 5,8 and 15), 24 hour specimens were collected. Following collection, the urine was acidified by the addition of glacial acetic acid in the proportion of $2 \mathrm{ml}$. per $100 \mathrm{ml}$. urine. Feces specimens were collected on diapers. On the first day, these

4 An estimate of the calcium content of the food eaten, based on the nurses' notes, would indicate that these surprisingly high values for $\mathrm{Ca}$ intake are reasonable, as the estimated cumulative $\mathrm{Ca}$ intake is only about 17 per cent lower than the analytical value.

5 The $\mathrm{Ca}-45$ was obtained on allocation from the Oak Ridge Installation of the Atomic Energy Commission. Authorization for the use of $80 \mu \mathrm{c}$. of $\mathrm{Ca}-45$ in a moribund patient with gargoylism was granted through the Sub-Committee on Human Applications. were pooled to constitute eight hour specimens; on subsequent days, 24 hour specimens were analyzed.

Autopsy. Representative samples of mineralized and soft tissues were removed at autopsy and analyzed (see Tables I to III). In the case of certain hard tissues (Table II), the analysis of the whole section was supplemented by analysis of scrapings, obtained with a dental burr at anatomically defined regions $(22,23)$.

\section{Analytical procedures}

Calcium analysis. Blood calcium content was determined by direct precipitation of the calcium from the serum as the oxalate, which was titrated with perchloratoceric acid (24). Urine calcium was determined by precipitation of the calcium either directly from the urine or from an ash solution of the urine. Calcium contents of stool specimens were determined on fecal ash solutions. The coefficient of variation (standard deviation times 100 divided by the mean) of the calcium determinations was usually below 5 per cent.

Ca-45 analysis. $\mathrm{Ca}-45$ was determined by measuring the radioactivity of calcium oxalate samples which contained $4.0 \mathrm{mg}$. of $\mathrm{Ca}$. The solid samples were counted under a thin end-window ( $<1.5 \mathrm{mg}$. per $\left.\mathrm{cm}^{2}\right)$ GeigerMüller counter, connected to an automatic sample-changing device. Suitable standards were employed in all counting runs and all results are reported as corrected for decay from the day of injection. Counting errors varied, 
but their coefficients of variation were generally less than 10 per cent. The term "dose" refers to the quantity of $\mathrm{Ca}-45$ injected.

The analytical techniques employed have been described in detail by Bronner, Harris, Maletskos, and Benda (3).

\section{RESULTS}

\section{Serum}

When the serum data are plotted on semilogarithmic coordinates (Figure 1), they fall on a complex curve which is approximated by the following equation:

$$
\begin{aligned}
C_{t}=0.177 \mathrm{e}^{-8.1 \mathrm{t}} & +0.061 \mathrm{e}^{-0.322 \mathrm{t}} \\
+ & \left.0.035 \mathrm{e}^{-0.034 \mathrm{t}}+0.018 \mathrm{e}^{-0.006 \mathrm{t}}, \quad 1\right)
\end{aligned}
$$

where

$$
\begin{aligned}
\mathrm{C}_{\mathrm{t}} & =\text { Per cent of dose per mg. of } \mathrm{Ca} \text { in serum } \\
\mathrm{t} & =\text { and }
\end{aligned}
$$

TABLE I

Specific activity of selected soft tissues obtained at autopsy of a patient with gargoylism who had received by intravenous injection $80 \mu c$. of $\mathrm{Ca}-45 \mathrm{Cl}_{2} 16$ days previously

\begin{tabular}{lc}
\hline \multicolumn{1}{c}{ Tissue } & $\begin{array}{c}\text { Ca-45 content } \\
(\% \text { dose/Gm. Ca })\end{array}$ \\
\hline Serum & 2.26 \\
Brain & $3.06^{*}$ \\
Spleen & 3.17 \\
Kidney & 2.79 \\
Liver & 1.55 \\
Diaphragm & 2.52 \\
Intestinal tract & 3.08 \\
Duodenum & 1.67 \\
& 1.57 \\
Jejunum & 2.10 \\
Ileum & $2.04-2.82 \dagger$ \\
Ascending colon & 2.42 \\
Transverse colon & 3.26 \\
Descending colon & $1.51-1.76$ \\
Sigmoid flexure & 1.25 \\
and rectum & 2.10 \\
Bile & 1.44 \\
& 1.44 \\
Washings & 2.92 \\
Small intestine & content: 0.692 \\
Colon & mg./ml.) \\
Sigmoid flexure & 1.54 \\
and rectum & 0.75 \\
& 1.01 \\
\end{tabular}

* Two entries indicate determinations on two samples of tissue.

$+A$ dash indicates the range of determinations on more than two samples of tissue.
TABLE II

Ca-45 contents of bone scrapings obtained at autopsy of a patient with gargoylism who had received by intravenous injection $80 \mu c$. of $\mathrm{Ca}_{-45} \mathrm{Cl}_{2} 16$ days previously

\begin{tabular}{ccc}
\hline $\begin{array}{c}\text { Tissue, sample no., and } \\
\text { description* }\end{array}$ & $\begin{array}{c}\text { Ca content } \\
(m g . C a / G m .)\end{array}$ & $\begin{array}{c}\text { Ca-45 content } \\
(\% \text { dose/Gm.Ca })\end{array}$ \\
\hline
\end{tabular}

Calvarium

$\begin{array}{lll}\text { A1 } & 251 & 0.083 \\ \text { A2 } & 228 & 0.071 \\ \text { A3 } & 221 & 0.143 \\ \text { A4 } & 211 & 0.195 \\ \text { A5 } & 194 & 0.217 \\ \text { A6 } & 239 & 0.166\end{array}$

Premolar tooth, unerupted

E1 Enamel $372 \quad 0.0205$

E2 $349 \quad 0.0180$

E3 $338 \quad 0.0155$

DEJ Dentino-enamel junction $\quad 428 \quad 0.0137$

D1 Dentin $312 \quad 0.000$

D2 299.0 .0780

$\begin{array}{llll}\text { D3 } & & 366 & 0.040 \\ \text { D4 } & \text { Internal dentin } & 386 & 0.1047\end{array}$

Ulna

C1 Spongy bone, distal head $294 \quad 0.119$

C2 Endochondral bone, distal head

C3 Subepiphyseal region $\quad 287 \quad 0.178$

C4 Trabecular spicules $\quad 228 \quad 0.133$

C5 Spicules 2650.106

D2 Subsurface cross segment $203 \quad 0.217$

D3 Central cross segment $389 \quad 0.220$

Ulna, shaft

B1 $320 \quad 0.0572$

B2 $213 \quad 0.0809$

B3 $\quad 294 \quad 0.0497$

$\begin{array}{lll}\text { B4 } & 322 & 0.0448\end{array}$

Ulna, proximal end

E1 Subepiphyseal $\quad 222 \quad 0.212$

E2 Trabecular 153 . 0.170

E3
region $\quad 215 \quad 0.186$

Metacarpal bone

Central $\quad 223 \quad 0.184$

Marrow area $\quad 240 \quad 0.151$

* See Figure 2 for location of sampling sites.

This equation is not valid for the first five minutes of the study and therefore its first term has little significance. Its general course resembles that observed in other children $(5,7)$, but differs from these significantly (Table IV), inasmuch as the exponents of the second and third terms of equation 1) are only about one-tenth of the corresponding terms of the normal boys, and are also smaller than those of the adult. The exponent of the fourth term is as fast as that of the fourth term in the equation of the adult, but much slower than 

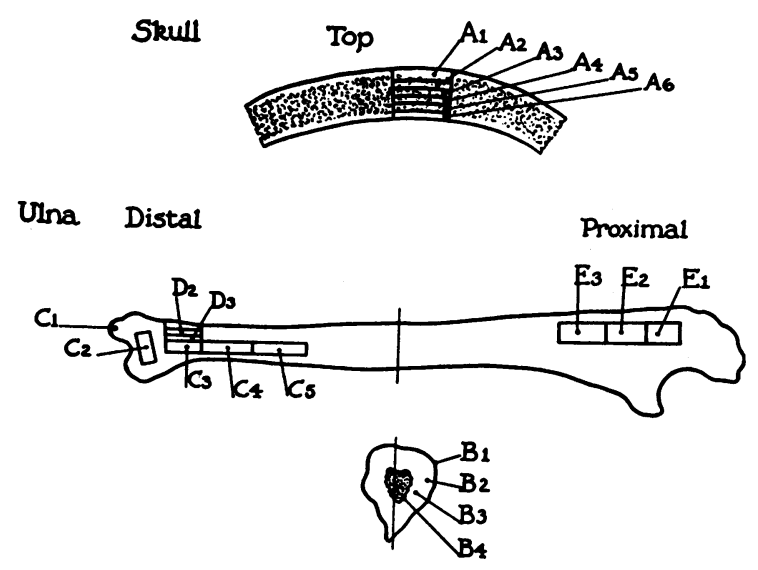

Tooth

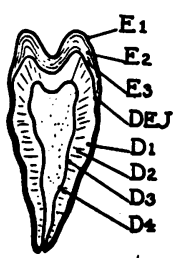

Fig. 2. Diagrammatic Localization of Sampling Sites for ANalyses Summarized in Table II

Samples were obtained with the aid of a dental burr.

TABLE III

Specific activity of selected hard tissues obtained at autopsy of a patient with gargoylism who had received by intravenous injection $80 \mu c$. of $\mathrm{Ca}-45 \mathrm{Cl}_{2} 16$ days previously

\begin{tabular}{lcc}
\hline \hline \multicolumn{1}{c}{ Tissue } & $\begin{array}{c}\text { Ca content } \\
(\mathrm{mg} . \mathrm{Ca} / \mathrm{Gm} .)\end{array}$ & $\begin{array}{c}\text { Ca-45 content } \\
(\% \text { dose } / \mathrm{Gm} . \mathrm{Ca})\end{array}$ \\
\hline Spine, thoracic section & 106 & 0.155 \\
Sixth left rib & 102 & 0.138 \\
Sixth right rib & 152 & 0.197 \\
Seventh left rib & 194 & 0.195 \\
Seventh right rib & 158 & 0.198 \\
Sternal cartilage, left & 111 & 0.217 \\
Sternal cartilage, right & 1.08 & 1.45 \\
Sternum & 1.90 & 1.76 \\
Skull, calvarium & 47.7 & 0.460 \\
Great wings, sphenoid bone & 172.4 & 0.271 \\
Left ulna & & 0.178 \\
Posterior end & 123 & \\
Posterior shaft & 119 & 0.202 \\
Anterior shaft & 125 & 0.088 \\
Anterior end & 189 & 0.102 \\
Metacarpal bone & 75.6 & 0.139 \\
Alveolar bone & 314 & 0.329 \\
Teeth & & 0.215 \\
Upper left deciduous canine & 354 & \\
Lower left deciduous canine & 381 & 0.054 \\
Upper right deciduous molar & 328 & 0.025 \\
Lower right deciduous molar & 331 & 0.033 \\
\hline & & 0.012 \\
\hline
\end{tabular}

TABLE IV

Comparison of exponents in serum disappearance equations*

\begin{tabular}{lll}
\hline \hline Boys $\dagger$ & $\begin{array}{c}\text { Young } \\
\text { adult }\end{array}$ & $\begin{array}{c}\text { Gargoyle } \\
\text { patient }\end{array}$ \\
\hline 0.281 & 0.713 & 0.135 \\
0.075 & 0.0112 & 0.0054 \\
0.004 & 0.0004 & 0.00057 \\
0.0005 & 0.00009 & 0.00010 \\
\hline * Dimension: minute ${ }^{-1}$. & \\
† Taken from Bronner and Harris $(7)$. &
\end{tabular}

the corresponding exponent in the equation of the normal boys.

A comparison of the last term of equation 1), with the coefficients, rate constants, and compartment sizes calculated by Krane, Brownell, Stanbury, and Corrigan (8), shows that the last term, with an intercept of 18.2 per cent dose per Gm. $\mathrm{Ca}$ and a slope of 0.138 per day, agrees well with the third term (Days 4 to 9 ) of equations reported by these authors for euthyroid adults. Similarly, the "calcium pool," $16.7 \mathrm{Gm}$., (per cent activity retained at Day 9 divided by the serum specific activity on Day 9) of our subject was comparable to that shown by Krane and collaborators (8) for euthyroid adults. However, on a body weight basis, the "pool" was much greater in our subject than in normal adults, as would be expected from the higher calcification rate seen in children.

Comparison of terms 2 and 3 of equation 1 ), with the comparable coefficients and rate constants of Krane and co-workers (8), shows (see also Table IV) that the processes which have given rise to these terms in our patient differ markedly from those observed in normal adults or normal children.

\section{Urine and feces data}

As would be expected, the specific activity data of serum and urine (Figure 1) can be considered to fall essentially on one curve, although the corresponding values for the urine tend, perhaps, to be lower than those for the serum. The very low output of calcium in the urine (Figure 3) may bear on this point.

The endogenous fraction of fecal calcium during the first five days is estimated from the mean serum specific activity during that period, on the assumption that the specific activity of the se- 
creted intestinal juice always equals that of the serum (5). As the mean specific activity of the serum between 0 and 120 hours was 0.0233 per cent dose per mg. $\mathrm{Ca}$, and as our patient had excreted 9.70 per cent of the dose in his stools during that period, his endogenous calcium output was $416 \mathrm{mg}$. or 11.0 per cent of the total calcium output in the feces. This value is similar to that observed by us in other instances ( 7 ).

In contrast with observations on normal, ambulatory patients $(1,5)$ or on terminal cancer patients $(2,4)$, the ratio of total urinary to fecal Ca-45 output was very much below unity (Figure 3 ). Geissberger (1) has reported ratios of this magnitude for patients with cardiac insufficiency. and steatorrhea, as have Laszlo and Spencer [quoted by Comar and Wasserman (9)] for two patients with cancer of the prostate.

\section{Cerebrospinal fuid}

The specific activity of the spinal fluid approached that of the serum between 5 and 48 hours after injection (Figure 1). Thereafter, its specific activity either was equal to or higher than that of the serum. Postmortem analysis of brain tissue indicated a specific activity of 0.031 per cent dose per mg. Ca, as opposed to the serum specific activity of 0.023 at the time of autopsy. This difference gives support to the possibility that the specific activity of the cerebrospinal fluid may actually have exceeded that of the serum.

\section{Bile}

Possibly the serum was diluted with calcium released by autolysis during the period which elapsed between death and autopsy (about seven hours); otherwise, the specific activities of bile fluid and serum ought to have been more nearly alike than was found (Table I). The observed specific activity of the bile fluid was of the same order of magnitude ( 0.002 per cent per $\mathrm{ml}$.) as reported for adult rats (25).

Singer, Maqsood, Medlen, and Comar (26) have very recently reported on the endogenous and biliary excretion of $\mathrm{Ca}-45$ in dogs. Their data indicate that, within 25 minutes of injection, 21 per cent of the activity found in the contents of the gastrointestinal tract (excluding the stomach) is found in the gall bladder. Our data show that the total activity found in the bile approximated 27 per cent of the activity washed out of the gastrointestinal tract, excluding the stomach (Table I).

\section{Soft tissues}

The specific activity of the small intestine increased in a posterior direction. Contrary to expectations, the relative specific activity of the intestine was not highest near the point where the common bile duct enters the duodenum ( 7 to 8 $\mathrm{cm}$. posteriorly of the pylorus). On the other hand, the low relative specific activity of the washings of the intestinal tract (Table I) suggests that even at a late stage in the patient's illness-when his food intake was rather small-labeled body calcium was still being diluted to a fair degree by unlabeled exogenous calcium.

Of some interest is the observation that several soft tissues (brain, spleen, liver, sections of the ileum and jejunum) had a higher specific activity than serum (Table I). Bronner (27) has recently shown that in very young rats the specific activity of many tissues is higher than that of serum. Inasmuch as the serum supplies tracer to a multi-

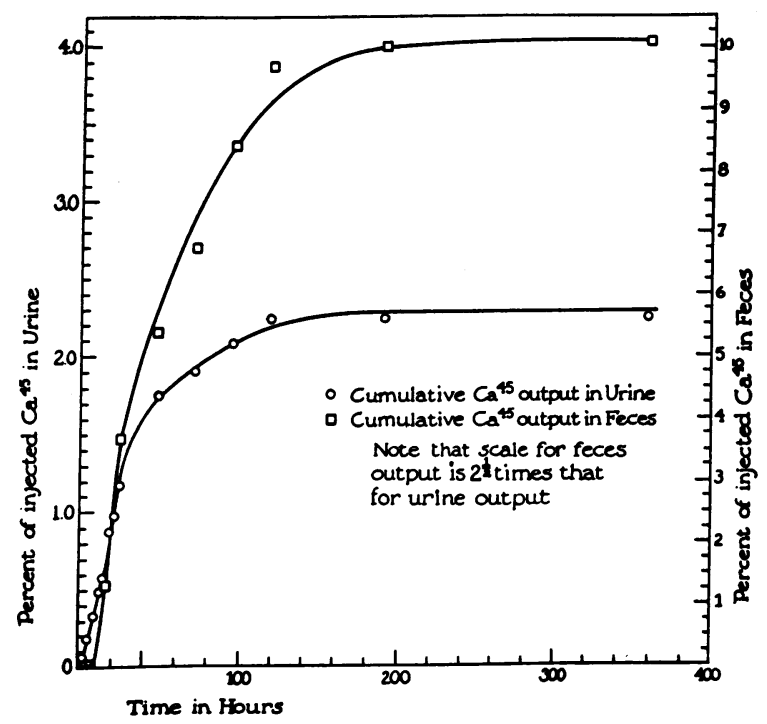

Fig. 3. Cumulative Output of Ca-45 in Urine and Feces of a Patient with Gargoylism Following Intravenous Administration of $80 \mu \mathrm{C}$. of $\mathrm{CA}^{-45 \mathrm{CL}_{2}}$

Average calcium output per day, first five days: urine, $23 \mathrm{mg}$.; range, 10 to 40 ; feces, $755 \mathrm{mg}$.; range, 470 to 1,065. On Days 8 and 15 , the output of calcium dropped to 3.4 and $4.1 \mathrm{mg}$. in the urine and to 226 and $104 \mathrm{mg}$. in the feces, respectively. 
compartment system, it is not surprising that its specific activity drops below that of some compartments.

\section{Mineralized tissues}

The data in Tables II and III are of interest because they indicate the fate of a single dose of $\mathrm{Ca}-45$ in relation to the architecture of the bones. It is apparent, as has been reported by others $(28-36)$, that the most highly calcified areas contain the smallest quantity of isotope. Thus, the extremities of the ulna showed more labeling than the shaft, undoubtedly because growth was still proceeding at the epiphyses, whereas the center of the shaft had stopped growing and was probably subject to remodelling only. The sternal cartilage of the ribs had a specific activity which was near that of the serum and which was approximately ten times as high as that of the bones [cf., Kulp, Eckelmann, and Schulert (37) for similar observations on strontium deposition].

\section{DISCUSSION}

The much slower rate of disappearance of $\mathrm{Ca}-45$ from the serum of our patient, as compared with

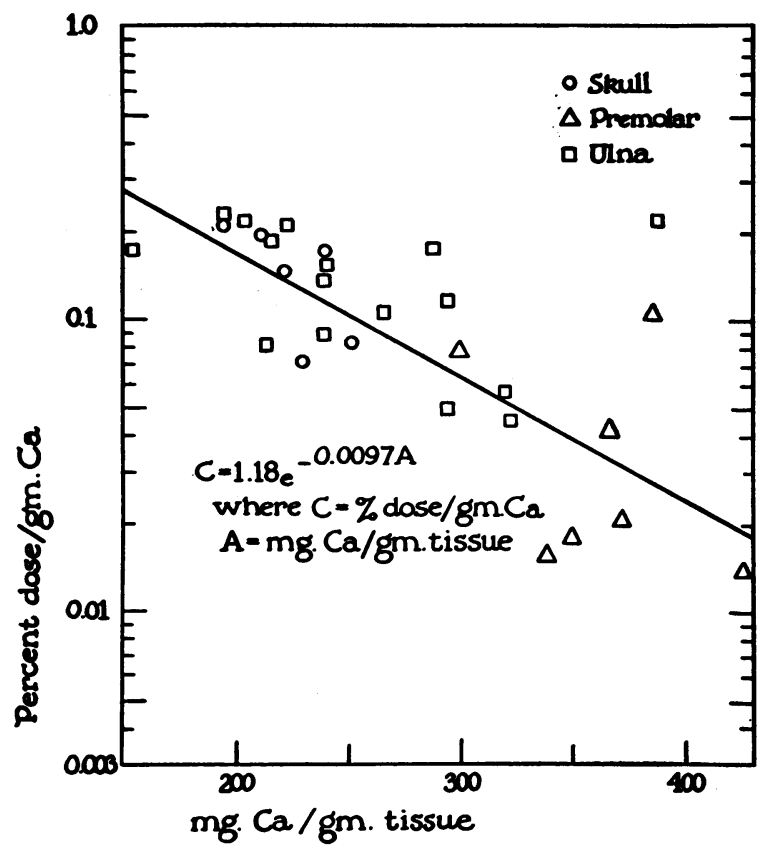

Fig. 4. Relationship Between Specific Activity and Calcium Content of Bones and Teeth in a Patient with Gargoylism 16 Days Following the INtravenous Administration of $80 \mu \mathrm{c}$. of $\mathrm{CA}^{-45 \mathrm{CL}_{2}}$ that of normal boys $(5,7)$, suggests a disturbed calcium metabolism due perhaps to interference with calcium deposition or accretion. It is not surprising, therefore, that evaluation of A ("accretion value") in accordance with the method of Bauer, Carlsson, and Lindquist (38) [see Bronner and Harris (7) for a description and discussion of this approach] reveals an average value of $0.54 \mathrm{Gm}$. per day. This is about one-fourth of the value calculated for a group of boys, and less than the value calculated for two young men (7). The average $E$ value, which represents the exchangeable fraction of body calcium $(7,38)$ of our patient, was $2.8 \mathrm{Gm}$., or 0.93 per cent of an estimated body calcium content of $300 \mathrm{Gm} .^{6}$ This value is comparable to those we calculated for other subjects (7).

Conceivably, the inability to deposit calcium, as indicated by the accretion value, is related to the accumulation of abnormal polysaccharide materials similar to those reportedly found in liver and spleen $(16,18-20)$. Chondroitin-like materials have recently been reported to occur in bone (40).

Because our patient's urinary output of $\mathrm{Ca}-45$ was depressed, though his output of endogenous calcium in the feces was within the normal range, his absorption of calcium may have been altered, but his death precluded further studies.

If the data of Table II are plotted on semilogarithmic coordinates (Figure 4) they fall along a straight line which is expressed (method of least squares) by the equation

where

$$
\mathrm{C}=1.18 \mathrm{e}^{-0.0097 \mathrm{~A}} \text {, }
$$

$\mathrm{C}=$ Specific activity (per cent of dose per $\mathrm{Gm}$. of $\mathrm{Ca}$ ), and

$\mathrm{A}=$ Calcium content of hard tissue ( $\mathrm{mg}$. of $\mathrm{Ca}$ per $\mathrm{Gm}$. of tissue).

This relationship is significant $(p=0.02)$ and is a measure of calcification in this individual. Engfeldt, Engström, and Zetterström (31) have hypothesized a similar relationship for the uptake of $\mathrm{P}-32$, although their diagram does not indicate

${ }^{6}$ Mitchell, Hamilton, Steggerda, and Bean (39) estimate the Ca content of a normal boy weighing $16.4 \mathrm{Kg}$. as $185 \mathrm{Gm}$., and that of a normal 10 year old boy as 396 $\mathrm{Gm}$. We have assumed our patient's body calcium content lay between these limits. 
the exponential nature of the relationship. Plumlee, Hansard, Comar, and Beeson (41) have also reported an inverse relation between specific activity of calcium in bones of the bovine fetus and fetal age, but again not as an exponential function. Rogers, Weidmann, and Jones (33) have discussed the difficulty of interpreting these observations from the point of view of mechanisms.

On the whole there is good agreement between the data in Tables II and III, even though the size of the sample was very small in the case of the analyses reported in Table II; this shows that the sampling of bone with a dental burr at well-defined anatomical points can provide both accuracy and definition (23). This method should prove very helpful as a quantitative adjunct to autoradiography.

The findings listed in Tables II and III confirm the observations of Sognnaes, Shaw, and Bogoroch (42) that the teeth do not participate in the general metabolism of calcium. Thus, unerupted teeth showed some labeling, although much less than skeletal structures, while deciduous teeth had almost negligible radioactivity. The two deciduous canine teeth analyzed in toto averaged $168 \mathrm{mg}$. of calcium. If it is assumed that the calcium content of this patient's body was 300 $\mathrm{Gm} .{ }^{6}$ then the canine teeth could have contained nearly 0.168 times 100 over 300 or 0.06 per cent of the labeled calcium when, in fact, they contained one-tenth this quantity.

In the case of one complete metacarpal bone removed at autopsy, a similar calculation would have led to an expected $\mathrm{Ca}-45$ content of 0.01 per cent. This value was found experimentally and indicates high metabolic activity. If ossification was delayed in this as compared to other bones [ossification is often delayed in the metacarpal bone centers of patients with gargoylism (13)], one might expect a relatively higher calcification rate leading to greater concentration of the isotope. In addition, the calcium content of the metacarpal bone as a whole was only $75.6 \mathrm{mg}$. of $\mathrm{Ca}$ per $\mathrm{Gm}$. as contrasted with the higher $\mathrm{Ca}$ content of the bone scrapings (cf., Figure 4).

The analysis of the calvarium (Tables II and III) indicates that calcification was not primarily the cause of its immense thickening. The level of the specific activity of the exterior of the calvarium was low, approximating that of the teeth; at the interior, the calvarium had a specific activity typical of most bony tissues. Its rate of calcification was similar to that of the other hard tissues (Figure 4). Anderson, Emery, McAlister, and Osborn (10) have recently reported that the Ca-45 content of the skull of a myelomatous patient was $0.0096 \mu \mathrm{c}$. per $\mathrm{Gm}$. or 0.00062 per cent dose per $\mathrm{Gm}$. 60 days after administration of the isotope. Our patient's skull contained 0.0313 per cent dose per $\mathrm{Gm} .15$ days after administration of the Ca-45. Even if his level had dropped by half at the end of 60 days, our patient's skull would still have contained over 25 times more isotope than reported for the skull of the myelomatous adult.

Because Anderson and collaborators (10) reported that the $\mathrm{Ca}-45$ tended to concentrate in the myelomatous regions, it is difficult to know whether the higher isotope level of the skull of our patient with gargoylism was the result of abnormal metabolic activity or whether the lower level in the myelomatous skull was due to preferential deposition in the myelomatous regions.

\section{SUMMARY AND CONCLUSIONS}

1. The rate of disappearance of $\mathrm{Ca}-45$ from the serum of a 10 year old patient with terminal gargoylism is described by the following equation:

$$
\begin{aligned}
& C_{t}=0.177 \mathrm{e}^{-8.1 \mathrm{t}}+0.061 \mathrm{e}^{-0.322 t} \\
& +0.035 \mathrm{e}^{-0.034 t}+0.018 \mathrm{e}^{-0.006 t} \text {, } \\
& \text { where } \\
& \mathrm{C}_{\mathrm{t}}=\text { Specific activity of the serum (per cent } \\
& \text { of dose per mg. of } \mathrm{Ca} \text { ), and } \\
& \mathbf{t}=\text { Time (hours). }
\end{aligned}
$$

The exponents in the second and third terms of this equation, valid for 15 days, indicate an appreciably slower rate of disappearance than observed heretofore in normal boys and one young adult. The exponent in the fourth term indicates a rate comparable to that of normal adults, but slower than seen in normal boys.

2. The urinary calcium output of this patient was severely depressed, so that the urinary-fecal partition ratio of $\mathrm{Ca}-45$ was 0.24 , as contrasted with a more normal range of 1 to 2 . The specific activities of serum and urine were found to be alike. 
3. Fecal output of calcium and $\mathrm{Ca}-45$ was in the normal range. The endogenous fecal output of this patient was calculated to equal $83 \mathrm{mg}$. per day, or 11.0 per cent of his average total excretion of calcium in the feces. This value is similar to that observed in other humans.

4. The depressed rate of disappearance of the injected $\mathrm{Ca}-45$ from the blood is consistent with the possibility of decreased calcium deposition. The accretion value $\mathrm{A}, 0.54 \mathrm{Gm}$. of $\mathrm{Ca}$ per day, was much lower than that calculated for normal boys. The exchangeable fraction of body calcium, E, was 0.93 per cent of his estimated body calcium content of $300 \mathrm{Gm}$. This value is comparable to the $E$ value of more normal subjects.

5. Data on the level of tracer in the soft tissues (brain, liver, spleen, gastrointestinal tract) obtained at necropsy 16 days after the start of the study were consistent with similar data in animals.

6. The level of $\mathrm{Ca}-45$ in the mineralized tissues varied inversely and exponentially with the level of calcium in bone and tooth samples obtained with a dental burr at anatomically defined loci. This indicates that the labeling of calcified tissues corresponded to the rate of calcium deposition. Analyses of gross bone specimens supported this conclusion.

7. In the absence of comparable data on normal humans, it is difficult to know whether and how gargoylism caused the abnormal calcium metabolism of our patient.

\section{ACKNOWLEDGMENTS}

We are indebted to Dr. R. F. Sognnaes of the Harvard School of Dental Medicine for many helpful suggestions in planning the analyses of the bone samples and for preparing and identifying the location of the bone and tooth samples. Mrs. Jean R. Moor and Mrs. Gloria Romano rendered skillful technical assistance. We are happy to express our appreciation to the staff of the Walter E. Fernald State School who nursed this patient with skill, self-sacrifice and patience.

\section{REFERENCES}

1. Geissberger, W. Die Calciumresorption und Retention beim Menschen nach intravenöser, oraler und rectaler Calciumverabreichung mit Bilanzen unter Anwendung von radioaktivem Calcium. Z. ges. exp. Med. 1952, 119, 111.

2. Bellin, J., and Laszlo, D. Metabolism and removal of $\mathrm{Ca}-45$ in man. Science 1952, 117, 331.

3. Bronner, F., Harris, R. S., Maletskos, C. J., and Benda, C. E. Studies in calcium metabolism.
Effect of food phytates on calcium-45 uptake in children on low-calcium breakfasts. J. Nutr. 1954, 54, 523.

4. Blau, M., Spencer, H., Swernov, J., and Laszlo, D. Utilization and intestinal excretion of calcium in man. Science 1954, 120, 1029.

5. Bronner, F., Harris, R. S., Maletskos, C. J., and Benda, C. E. Studies in calcium metabolism. The fate of intravenously injected radiocalcium in human beings. J. clin. Invest. 1956, 35, 78.

6. Bronner, F., Harris, R. S., Maletskos, C. J., and Benda, C. E. Studies in calcium metabolism. Effect of food phytates on calcium-45 uptake in boys on a moderate calcium breakfast. J. Nutr. 1956, 59, 393.

7. Bronner, F., and Harris, R. S. Absorption and metabolism of calcium in human beings, studied with calcium-45 in Ann. N. Y. Acad. Sci. 1956, 64, 314.

8. Krane, S. M., Brownell, G. L., Stanbury, J. B., and Corrigan, $\mathrm{H}$. The effect of thyroid disease on calcium metabolism in man. J. clin. Invest. 1956, 35, 874.

9. Comar, C. L., and Wasserman, R. H. Radioisotopes in the study of mineral metabolism in Progress in Nuclear Energy, Series VI. Biological Sciences, J. C. Bugher, J. Coorsaget, and J. Loutit, Eds. New York, McGraw-Hill, 1956, p. 153.

10. Anderson, J., Emery, E. W., McAlister, J. M., and Osborn, S. B. The metabolism of a therapeutic dose of $45 \mathrm{Ca}$ in a case of multiple myeloma. Clin. Sci. 1956, 15, 567.

11. Blau, M., Spencer, H., Swernov, J., Greenberg, J., and Laszlo, D. Effect of intake level on the utilization and intestinal excretion of calcium in man. J. Nutr. 1957, 61, 507.

12. Spencer, H., Laszlo, D., and Brothers, M. Strontium ${ }^{85}$ and calcium ${ }^{45}$ metabolism in man. J. clin. Invest. 1957, 36, 680.

13. Benda, C. E. Developmental Disorders of Mentation and Cerebral Palsies. New York, Grune and Stratton, 1952.

14. Lindsay, S., Reilly, W. A., Gotham, T. J., and Skahen, R. Gargoylism. II. Study of pathologic lesions and clinical review of twelve cases. Amer. J. Dis. Child. 1948, 76, 239.

15. Henderson, J. L., MacGregor, A. R., Thannhauser, S. J., and Holden, R. The pathology and biochemistry of gargoylism. A report of three cases with a review of the literature. Arch. Dis. Childh. 1952, 27, 230.

16. Brante, G. Gargoylism: a mucopolysaccharidosis. Scand. J. clin. Lab. Invest. 1952, 4, 43.

17. Dawson, I. M. P. The histology and histochemistry of gargoylism. J. Path. Bact. 1954, 67, 587.

18. Uzman, L. L. Chemical nature of the storage substance in gargoylism. Arch. Path. 1955, 60, 308.

19. Bishton, R. L., Norman, R. M., and Tingey, A. The pathology and chemistry of a case of gargoylism. J. clin. Path. 1956, 9, 305. 
20. Stacey, M., and Barker, S. A. Chemical analysis of tissue polysaccharides. J. clin. Path. 1956, 9, 314

21. Amprino, $R$. Uptake of ${ }^{25} \mathrm{~S}$ in the differentiation and growth of cartilage and bone in Ciba Foundation Symposium on Bone Structure and Metabolism, G. E. W. Wolstenholme and C. M. O'Connor, Eds. Boston, Little, Brown and Co., 1956, p. 89.

22. Sognnaes, R. F., and Volker, J. F. Studies on the distribution of radioactive phosphorus in the tooth enamel of experimental animals. Amer. J. Physiol. 1941, 133, 112.

23. Sognnaes, R. F., and Shaw, J. H. Salivary and pulpal contributions to the radiophosphorus uptake in enamel and dentin. J. Amer. dent. Ass. 1952, 44, 489.

24. Salomon, K., Gabrio, B. W., and Smith, G. F. A precision method for the quantitative determination of calcium in blood plasma. Arch. Biochem. 1946, $11,433$.

25. Greenberg, D. M., and Troescher, F. M. Study with radioactive isotopes of excretion of calcium and strontium by way of the bile. Proc. Soc. exp. Biol. (N. Y.) 1942, 49, 488.

26. Singer, L., Maqsood, M., Medlen, A. B., and Comar, C. L. Endogenous and biliary excretion of calcium-45 and strontium-89. Arch. Biochem. Biophys. 1957, 66, 404.

27. Bronner, F. Disposition of intraperitoneally injected calcium-45 in suckling rats. J. gen. Physiol. 1958. In press.

28. Hevesy, G. Ch., Levi, H. B., and Rebbe, O. H. Rate of rejuvenation of the skeleton. Biochem. J. 1940, 34, 532.

29. Amprino, R. Autoradiographic analysis of the distribution of labelled $\mathrm{Ca}$ and $\mathrm{P}$ in bone. Experientia 1952, 8, 20.

30. Amprino, R. Further experiments on the fixation in vitro of radiocalcium to sections of bone. Experientia 1952, 8, 380.

31. Engfeldt, B., Engström, A., and Zetterström, R. Renewal of phosphate in bone minerals. II. Radioautographic studies of the renewal of phosphate in different structures of bone. Biochim. biophys. Acta 1952, 8, 375.
32. Lacroix, P., Devis, R., and Schicks, E. Distribution of radiophosphorus in the long bones of adult rabbits. Experientia 1952, 8, 113.

33. Rogers, H. J., Weidmann, S. M., and Jones, H. G. Studies on the skeletal tissues. 3. The rate of exchange of the inorganic phosphate in different bones and parts of bones in various species of mammal. Biochem. J. 1953, 54, 37.

34. Engfeldt, B., and Hjertquist, S. O. Biophysical studies on bone tissue. $\mathrm{X}$. The in vivo and in vitro uptake of radioactive isotopes and ionic exchange reactions in bone tissue. Acta path. microbiol. scand. 1954, 35, 205.

35. Vincent, J. Recherches sur la constitution de l'os adulte. Thesis, Faculty of Medicine, Université Catholique de Louvain, 1955.

36. Weidmann, S. M. Studies on the skeletal tissues. 4. The renewal of inorganic phosphate in bones of various species of small mammal as a function of time. Biochem. J. 1956, 62, 593.

37. Kulp, J. L., Eckelmann, W. R., and Schulert, A. R. Strontium-90 in man. Science 1957, 125, 219.

38. Bauer, G. C. H., Carlsson, A., and Lindquist, B. Evaluation of accretion, resorption, and exchange reactions in the skeleton. Kungl. Fysiograf. Sällsk., Lund, Förhandl. 1955, 25, 1.

39. Mitchell, H. H., Hamilton, T. S., Steggerda, F. R., and Bean, H. W. The chemical composition of the adult human body and its bearing on the biochemistry of growth. J. biol. Chem. 1945, 158, 625.

40. Dziewiatkowski, D. D., Bronner, F., Di Ferrante, N., and Archibald, R. M. Some aspects of the metabolism of sulfate-S-35 and calcium-45 in the metaphyses of immature rats. Influence of $\beta$-estradiol benzoate. J. biophys. biochem. Cytol. 1957, 3, 151.

41. Plumlee, M. P., Hansard, S. L., Comar, C. L., and Beeson, W. M. Placental transfer and deposition of labeled calcium in the developing bovine fetus. Amer. J. Physiol. 1952, 171, 678.

42. Sognnaes, R. F., Shaw, J. H., and Bogoroch, R. Radiotracer studies on bone, cementum, dentin and enamel of rhesus monkeys. Amer. J. Physiol. 1955, $180,408$.

\section{SPECIAL NOTICE TO SUBSCRIBERS}

Post Offices will no longer forward the Journal when you move.

Please notify The Journal of Clinical Investigation, Business Office, 333 Cedar Street, New Haven 11, Conn., at once when you have a change of address, and do not omit the zone number if there is one. 